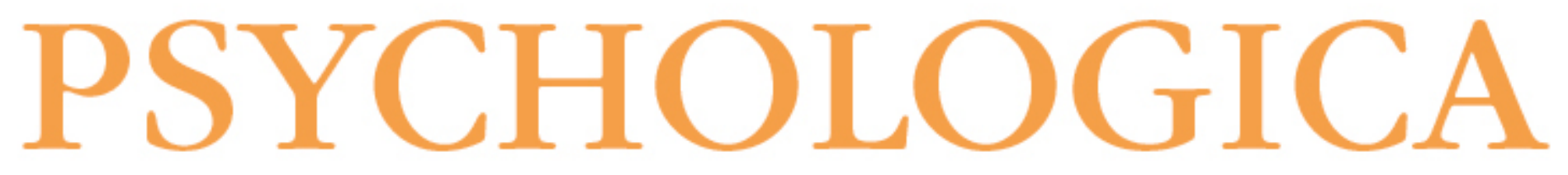

Reasons to search for couple and family therapy: a systematic literature review

Autor(es): $\quad$ Neumann, Angélica Paula; Wagner, Adriana

Publicado por: Imprensa da Universidade de Coimbra

URL

persistente: URI:http://hdl.handle.net/10316.2/38637

DOI: ～DOI:http://dx.doi.org/10.14195/1647-8606_58-1_2

Accessed : $\quad$ 26-Apr-2023 14:52:29

A navegação consulta e descarregamento dos títulos inseridos nas Bibliotecas Digitais UC Digitalis, UC Pombalina e UC Impactum, pressupõem a aceitação plena e sem reservas dos Termos e Condições de Uso destas Bibliotecas Digitais, disponíveis em https://digitalis.uc.pt/pt-pt/termos.

Conforme exposto nos referidos Termos e Condições de Uso, o descarregamento de títulos de acesso restrito requer uma licença válida de autorização devendo o utilizador aceder ao(s) documento(s) a partir de um endereço de IP da instituição detentora da supramencionada licença.

Ao utilizador é apenas permitido o descarregamento para uso pessoal, pelo que o emprego do(s) título(s) descarregado(s) para outro fim, designadamente comercial, carece de autorização do respetivo autor ou editor da obra.

Na medida em que todas as obras da UC Digitalis se encontram protegidas pelo Código do Direito de Autor e Direitos Conexos e demais legislação aplicável, toda a cópia, parcial ou total, deste documento, nos casos em que é legalmente admitida, deverá conter ou fazer-se acompanhar por este aviso. 


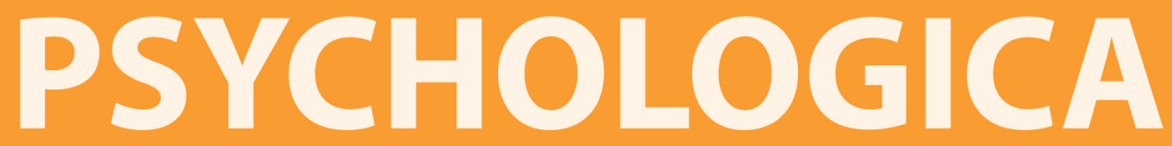

IMPRENSA DA UNIVERSIDADE DE COIMBRA COIMBRA UNIVERSITY PRESS

FACULDADE DE PSICOLOGIA E DE CIÊNCIAS

DA EDUCAÇÃO DA UNIVERSIDADE DE COIMBRA 


\title{
Reasons to search for couple and family therapy: A systematic literature review
}

\author{
Angélica Paula Neumann ${ }^{1}$ e Adriana Wagner ${ }^{2}$
}

\begin{abstract}
There is a gap in the literature regarding the process by which families and couples seek professional help. Little is known about the familial and environmental factors that influence this process. The goal of this study was to identify the reasons why couples and families search for couple and family therapy. A systematic literature review was conducted. Twenty-three articles have met the inclusion criteria. Content Analysis was used to identify the factors that influenced the help-seeking process. Four factors were identified: type of problem, previous sources of help, gender and relationship factors. Results showed that couples and families use a variety of resources before looking for couple and family therapy. Research into this area is still in its early stages. Further studies must be conducted to better understand this phenomenon.
\end{abstract}

Keywords: couple therapy; family therapy; help-seeking behaviors

1 Universidade Federal do Rio Grande do Sul (UFRGS), Porto Alegre, Rio Grande do Sul, Brasil. Doutoranda no Programa de Pós-Graduação em Psicologia da UFRGS. Endereço: Instituto de Psicologia, Programa de Pós-Graduação em Psicologia. Angélica Neumann foi Bolsista de Mestrado do Conselho Nacional de Desenvolvimento Científico e Tecnológico (CNPq) durante a realização da pesquisa. E-mail: angelicaneumann@gmail.com

2 Universidade Federal do Rio Grande do Sul (UFRGS), Porto Alegre, Rio Grande do Sul, Brasil. Professora Adjunta do Programa de Pós-Graduação em Psicologia da UFRGS. Endereço: Instituto de Psicologia, Programa de Pós-Graduação em Psicologia. Adriana Wagner é Bolsista de Produtividade em Pesquisa 1B pelo CNPq. E-mail: adrianawagner.ufrgs@hotmail. com 
Motivos para procurar terapias de casal e família: Uma revisão sistemática da literatura

\section{Resumo}

Existe uma lacuna na literatura a respeito do processo pelo qual famílias e casais passam ao procurar ajuda profissional. Pouco se sabe sobre os fatores familiares e contextuais que influenciam esse processo. O objetivo deste estudo foi identificar as razões que motivam a busca pelas terapias de casal e família. Uma revisão sistemática da literatura foi realizada. Vinte e três artigos atenderam aos critérios de inclusão. Foi utilizada a técnica da Análise de Conteúdo para identificar os fatores que influenciam no processo de busca de ajuda. Quatro fatores foram encontrados: tipo de problema, estratégias anteriores de ajuda, gênero e fatores relacionais. Os resultados evidenciam que as famílias e os casais lançam mão de vários recursos antes de buscar terapia. As pesquisas sobre o processo de busca de ajuda para as terapias de casal e família é ainda incipiente, indicando a necessidade de mais estudos sobre o tema.

Palavras-chave: terapia de casal; terapia de família; comportamento de busca de ajuda

\section{INTRODUCTION}

Seeking psychological help is not an easy task. It requires the identification of a problem and an admission of the inability to resolve it, which is often a painful process. Although psychotherapy is an important source of help, recognizing a problem may not always lead to the decision to seek help. Studies conducted in the United States of America, Australia and United Kingdom suggest that about two thirds of individuals with mental disorders were not receiving specialized health care (Burgess et al., 2009; Merikangas et al., 2010; McManus, Meltzer, Brugha, Bebbington, \& Jenkins, 2007).

Predicting the benefits of treatment (Nam et al., 2013) and having relatives who have previously used mental health services (Zartaloudi \& Madianos, 2010) are factors that may favor the search for professional help. Knowledge about mental disorders and the acceptance of having a mental condition also facilitate the search for help in individuals with depression (Pieters \& Heilemann, 2010), post-partum 
depression (Dennis \& Chung-Lee, 2006) and post-traumatic stress disorder (Sayer et al., 2009). Realizing the severity of the condition and the emotional stress associated with it may also trigger the help-seeking process (Reyes-Rodríguez, Ramírez, Davis, Patrice, \& Bulik, 2013).

On the other hand, issues such as difficulty accessing mental health services may prevent the search for professional help (Sayer et al., 2009), as well as unfamiliarity with the work of health professionals (Kaltman, Mendoza, Gonzales, \& Serrano, 2014) and previous unsatisfactory experiences with mental health professionals (Gulliver, Griffiths, \& Christensen, 2012). Self-stigmatization, that is, feelings of social inadequacy associated with seeking professional help, has also been found to influence this process (Vogel, Wade, \& Haake, 2006).

These results indicate that the study of therapy-seeking behaviors is a promising area of research; however, investigations on the topic have mostly focused on the search for individual counseling. There appears to be a gap in the literature regarding the process by which families and couples seek professional help, and little is known about the familial and environmental factors which influence this process. Studies have suggested that families may remain in conflict for over a decade before initiating therapy (Neumann \& Wagner, in press), since the identification of a problem does not necessarily lead them to seek professional help (Doss, Atkins, \& Christensen, 2003).

As such, several questions remain to be answered with regard to the help-seeking among families and couples, such as: Are couple and family therapy or counseling among the first choices for help in problematic situations? Do patients usually seek therapy of their own accord, or are they referred by other health professionals? Why do these individuals select couple or family therapy over other treatment options? Do all members of the couple or family agree to seek therapy? What factors, if any, can distinguish which couples or families will adhere to such a treatment and which patients will not? What factors trigger the help-seeking process?

The in-depth study of these issues may make important contributions to both the academic and clinical practices. Comprehend the factors involved in the help-seeking process and their repercussions on the therapeutic process is of major importance to clinical practitioners due to their influence on patient prognosis and on the development of adequate treatment plans. The clients themselves may also benefit from this knowledge, since the ability to identify the factors associated with help-seeking may help couples and families to achieve greater autonomy in the search for professional help. Public awareness campaigns may make an especially important contribution in this regard, due to their ability to clarify and inform potential clients of the purpose and value of couple and family therapy. Lastly, the identification of factors associated with help-seeking may help to design studies 
of the efficacy of different interventions, and of predictors of treatment adherence and outcomes.

Therefore, the goal of this study was to identify the reasons by which couples and families search for couple and family therapy. To achieve this purpose, a systematic literature review of current research on the topic was conducted, guided by the following research question: What factors are involved in the search for couple and family therapy?

\section{METHOD}

A systematic literature review was carried out according to Wright, Brand, Dunn, and Spindler (2007). The following databases were used: Academic Search Premier (EBSCO), Annual Reviews, Cambridge Journals, Directory of Open Access Journals (DOAJ), PsycINFO, JSTOR, Wiley Online Library, SAGE Journals, Springer Link and BVS-Psi, which includes articles from the Lilacs, Scielo, PePSIC and BVS - Health Virtual Library databases.

Pilot searches were conducted to select the most appropriate keywords for the literature review. They showed that no single descriptor was able to retrieve sufficiently representative results. Therefore, searches were made using combinations of the terms couple therapy and family therapy with the words help-seeking, reasons, search, why and demand. This procedure resulted in ten combinations of keywords (couple therapy help-seeking, couple therapy reasons, couple therapy search, couple therapy why, couple therapy demand, family therapy help-seeking, family therapy reasons, family therapy search, family therapy why and family therapy demand).

All searches were initially conducted using the all fields search tag, and no limits were placed on the year of publications. Although this procedure proved adequate for most of the databases searched, a preliminary assessment of the results obtained showed that some databases retrieved an especially high number of articles on topics that were unrelated to the current study. Therefore, it was decided that when a keyword combination (e.g., "family therapy why") retrieved over 400 results, the search would be restricted to the title, abstract and keyword fields. Lastly, all searches were limited to full text articles and, when possible, to psychology and clinical psychology, to help direct the search toward our major areas of interest. These parameters were adapted to the specificities of each database. Only articles published in English, Portuguese and Spanish were considered since these were the languages in which the authors were fluent. 
The literature search retrieved 6839 results, from which 3568 were duplicates, making for a total of 3271 articles. Firstly, titles and abstracts were assessed for the following inclusion criteria: having family or couple therapy as the main topic and discussing the help-seeking process. This procedure led to the selection of 35 articles for further analysis, once that 3236 studies did not attend to the inclusion criteria. After these 35 articles were fully read, 23 were found to meet inclusion criteria and were included in the review. The 12 remaining articles were excluded since they did not focus on the therapy-seeking process of couples and families. These articles focused instead on themes like the emergence of couple and family therapy in specific countries, family and couple conflicts and help-seeking for sexual therapy.

To provide a clearer description of the context of the publications on the topic, the following information was also collected from each article: year of publication, journal, type of study (empirical, theoretical or experience report), origin of the study, study design (qualitative, quantitative or mixed), type of therapy discussed (couple or family therapy) and major focus of the study (help-seeking as the main focus or as a peripheral focus). These data were analyzed using frequency analysis. Most of these variables were explicitly described in the papers. However, since, in some cases, the type of study was somewhat difficult to determine, the following classification system was used to differentiate between empirical studies, theoretical studies and experience reports, according to Teixeira, Lassance, Silva, and Bardagi (2007). Studies that presented clear descriptions of a method and results were considered empirical. Literature reviews and conceptual studies were classified as theoretical, as were the theoretical studies that used case studies to illustrate specific points. Case studies or reports of professional experience which only contained brief theoretical discussions were considered experience reports.

Lastly, a Thematic Content Analysis (Bardin, 2011) was conducted to identify the factors involved in the search for couples and family therapy. This method was used to analyze the Results section of all the articles which met inclusion criteria. In the case of theoretical articles and experience reports, which do not include a Results section, content analysis was applied to the entire length of the paper. Initially, the first author read the data and proposed six factors for the analysis: personal factors, relationship factors, gender, cultural aspects, previous sources of help and type of problem. After that, both authors analyzed the data and compared the results. This procedure led to the exclusion of two factors (personal factors and cultural aspects), on which the authors did not agree. Data was analyzed one more time by both authors, and then it was compared again. As the authors agreed about at least $75 \%$ of the data this time (Olabuénaga, 2003), the four factors structure were maintained. The authors discussed the aspects that were not in harmony 
and reached an agreement. The following criteria proposed by Bardin (2011) were adopted in the current investigation: a) mutual exclusion: the same excerpts of the text were not included in more than one factor; b) homogeneity: the factors were homogeneous about their themes; c) relevance: the factors were chosen according to the data and the theoretical and practical relevance; d) productivity: the factors maintained were the ones which have a minimum of four studies, so as inferences could be made; and e) fidelity: the data were analyzed by the same criteria by both authors.

\section{RESULTS}

The articles that attended the inclusion criteria were published between 1988 and 2013. A total of $65 \%(n=15)$ of these articles were published in the last decade, with $39 \%(n=9)$ having been published in the last five years. The articles were published in 18 different journals. The Journal of Marital and Family Therapy contained three of the articles included, while the Journal of Family Psychology, The Family Journal: Counseling and Therapy for Couples and Families and the Contemporary Family Therapy Journal contained two articles each. The remaining articles were drawn from one journal each.

Table 1 shows that most of the articles discussed couple therapy only. The remaining articles focused primarily on family therapy, although some discussed both family and couple therapy. Almost half of the analyzed studies focused specifically on the help-seeking process. In the other ones, help-seeking had a more peripheral focus, and was discussed as a part of a larger issue. Most articles were empirical, and used quantitative methods. Half of these studies were conducted in the United States of America, three did not specify a location and the remaining ones reported on studies conducted in Germany, Canada, China and Norway. 
Table 1

Characteristics of the Studies Reviewed

\begin{tabular}{|c|c|c|c|c|}
\hline & $\begin{array}{c}\text { Couple Therapy } \\
f(\%)\end{array}$ & $\begin{array}{c}\text { Family Therapy } \\
f(\%)\end{array}$ & $\begin{array}{c}\text { Couple and Family } \\
\text { Therapy } \\
f(\%)\end{array}$ & $\begin{array}{c}\text { Total } \\
(\%)\end{array}$ \\
\hline Therapy discussed & $13(56.5)$ & $7(30.4)$ & $3(13)$ & $23(100)$ \\
\hline \multicolumn{5}{|l|}{ Help seeking specificity } \\
\hline Specific & $6(26.1)$ & $3(13.0)$ & $1(4.3)$ & $10(43.5)$ \\
\hline Peripheral & $7(30.4)$ & $4(17.4)$ & $2(8.7)$ & $13(56.5)$ \\
\hline \multicolumn{5}{|l|}{ Type of study } \\
\hline Empirical & $11(47.8)$ & $4(17.4)$ & $1(4.3)$ & $16(69.5)$ \\
\hline Theoretical & $1(4.3)$ & $1(4.3)$ & $1(4.3)$ & $3(13.0)$ \\
\hline Experience report & $1(4.3)$ & $2(8.7)$ & $1(4.3)$ & $4(17.4)$ \\
\hline \multicolumn{5}{|l|}{ Study design } \\
\hline Qualitative & $1(6.2)$ & - & - & $1(6.2)$ \\
\hline Quantitative & $10(62.5)$ & $3(18.7)$ & $1(6.2)$ & $14(87.5)$ \\
\hline Mixed design & - & $1(6.2)$ & - & $1(6.2)$ \\
\hline \multicolumn{5}{|l|}{ Origin of studies } \\
\hline United States & $5(31.2)$ & $3(18.7)$ & $1(6.2)$ & $9(56.2)$ \\
\hline Others & $3(18.7)$ & $1(6.2)$ & - & $4(25)$ \\
\hline N.I. & $3(18.7)$ & - & - & $3(18.7)$ \\
\hline
\end{tabular}

Note. N.I. $=$ Not informed

The analysis revealed four factors which were found to influence the help-seeking process for couple and family therapy. These factors were named "type of problem", "previous sources of help", "gender" and "relationship factors". Table 2 describes the studies which composed each factor, as well as the type of the studies (empirical, theoretical or experience report) and the methodological design used (qualitative, quantitative or mixed). 
Table 2

Factor distribution

\begin{tabular}{|c|c|c|c|c|}
\hline & Type of problem & $\begin{array}{c}\text { Previous sources of } \\
\text { help }\end{array}$ & Gender & Relationship factors \\
\hline \multicolumn{5}{|l|}{ Couples therapy } \\
\hline \multicolumn{5}{|l|}{ Empirical } \\
\hline Qualitative & $1(\mathrm{a})$ & $1(\mathrm{a})$ & - & - \\
\hline Quantitative & $6(b, e, f, h, j, l)$ & $3(f, i, j)$ & $5(\mathrm{e}, \mathrm{f}, \mathrm{h}, \mathrm{j}, \mathrm{q})$ & $4(h, i, j, k, s)$ \\
\hline Mixed design & - & - & - & - \\
\hline Experience & $1(\mathrm{r})$ & - & - & - \\
\hline Theoretical & - & - & $1(\mathrm{~m})$ & - \\
\hline Total & 8 & 4 & 6 & 5 \\
\hline \multicolumn{5}{|l|}{ Family therapy } \\
\hline \multicolumn{5}{|l|}{ Empirical } \\
\hline Qualitative & - & - & - & - \\
\hline Quantitative & $2(\mathrm{u}, \mathrm{v})$ & $2(\mathrm{~d}, \mathrm{v})$ & - & - \\
\hline Mixed design & - & $1(\mathrm{c})$ & - & - \\
\hline Experience & $2(\mathrm{~g}, \mathrm{p})$ & - & - & - \\
\hline Theoretical & - & $1(\mathrm{n})$ & - & - \\
\hline Total & 4 & 4 & 0 & 0 \\
\hline \multicolumn{5}{|l|}{$\mathrm{C}$ and $\mathrm{F}$ therapy } \\
\hline \multicolumn{5}{|l|}{ Empirical } \\
\hline Qualitative & - & - & - & - \\
\hline Quantitative & $1(w)$ & - & - & - \\
\hline Mixed design & - & - & - & - \\
\hline Experience & $1(\mathrm{o})$ & - & - & - \\
\hline Theoretical & - & - & $1(t)$ & - \\
\hline Total & 2 & 0 & 1 & 0 \\
\hline Total & 14 & 8 & 7 & 5 \\
\hline
\end{tabular}

Note. $\mathrm{C}$ and $\mathrm{F}$ therapy = Couples and family therapy; $\mathrm{a}=$ Adams, Aducci, Anderson, Johnson, Zheng, and Liu (2013); b = Atkins, Marín, Lo, Klann, and Hahlweg (2010); c = Awosan, Sandberg, and Hall (2011); d = Bermúdez, Kirkpatrick, Hecker, and Torres-Robles (2010); e = Boisvert, Wright, Tremblay, and McDuff (2011); $\mathrm{f}=$ Bringle and Byers (1997); $\mathrm{g}=$ Brown (2008); h = Doss, Atkins and Christensen (2003); i = Doss, Rhoades, Stanley, and Markman (2009); $\mathrm{j}=$ Doss, Simpson, and Chrisensen (2004); $\mathrm{k}$ = Doss and Christensen (2006); $\mathrm{l}=$ Ehrensaft and Vivian (1996); $\mathrm{m}=$ Englar-Carlson and Shepard (2005); n = Fang and Wark (1998); o = Féres-Carneiro (1988); p = Féres-Carneiro and Magalhães (2008); q = Ficher, Zuckerman, and Steinberg (1988); r = Gomes and Levy (2010); s = McCrady, Epstein, Cook, Jensen, and Ladd (2011); t = O'Brien (1988); u = Ogden and Hagen (2009); v = Oliver, Searight, Lightfoot, and Sharon (1998); w = Smock, McWey, and Ward (2006).

Type of problem. The types of problem reported by couples and families were the most frequently discussed topics in the articles analyzed. Eight articles investigated the most common conflicts cited as reasons for seeking couple therapy, while four studies focused on family therapy and two studies addressed both types of intervention. Most of these were empirical studies with quantitative designs 
(see Table 2). These investigations identified over 25 problems cited by patients as reasons for seeking couple therapy. The most frequently reported issues included emotional distance between partners, frequent conflicts, troubled communication and concerns about marital separation. However, issues involving children, sexuality, specific marital difficulties, time spent together and a wish to improve one's relationship were also commonly reported by patients undergoing couples therapy (Adams et al., 2013; Boisvert, Wright, Tremblay, \& McDuff, 2011; Doss, Simpson, \& Christensen, 2004, Doss et al., 2003, Bringle \& Byers, 1997, Smock, McWey, \& Ward, 2006, Féres-Carneiro, 1998).

It is important to note that infrequent problems may be just as significant to the couples who seek for help as the frequent ones. For instance, while infidelity is not among the most frequently reported problems in therapy, one study showed that couples who seek treatment after experiencing such an issue tend to have higher rates of marital conflict and more symptoms of depression than those who do not have a history of infidelity (Atkins, Marín, Lo, Klann, \& Hahlweg, 2010).

Furthermore, studies show that the problems reported by couples upon starting therapy may not be the only significant problems in their lives. For instance, although marital violence is a serious concern, it was found that it may not always be reported in the first therapy sessions, since its low frequency and instability may lead individuals to consider it secondary to other problems, or not to consider it a problem at all (Ehrensaft \& Vivian, 1996). These hypotheses suggest that the way in which problems are presented in the search for therapy may not reflect their actual magnitude. Sometimes, the relationship difficulties may be obscured by parenting issues, and couples with troubled relationships may make their first contact with mental health services as part of an attempt to seek help for their children (Gomes \& Levy, 2010).

This pattern is very common in family therapy, where the stated reasons for entering treatment are often sibling fights, a 'problem' child, or other situations for which parents do not consider themselves responsible (Brown, 2008, Smock et al., 2006, Féres-Carneiro, 1998). In more serious situations, it was found that families may enter therapy due to mandatory indications by official institutions. This is often the case for the families of child and adolescent offenders, or of youth with most serious behavioral problems (Ogden \& Hagen, 2009; Oliver, Searight, \& Lightfoot, 1988). Other reasons that were found to influence the help-seeking for family therapy were parenting difficulties, financial problems and emotional overload (Féres-Carneiro \& Magalhães, 2008, Smock et al., 2006).

Previous sources of help. Four studies discussed the way in which couples coped with their problems prior to starting therapy, and four studies investigated the 
family's perspective on this issue. Most of these studies were empirical, and relied mostly on quantitative data (Table 2). Studies of the problem-solving strategies used by couples found that, before deciding to seek psychotherapy, many couples read relationship books and/or attended marriage workshops and courses in an attempt to resolve their difficulties (Doss, Rhoades, Stanley, \& Markman, 2009). Although previous experience with couples therapy increased the likelihood of selecting it as a treatment option in the future (Bringle \& Byers, 1997, Doss et al., 2004), many individuals first sought assistance from family and friends before deciding to seek professional help (Adams et al., 2013).

Most of the studies about the previous sources of help used by families researched the perspective of families in cultural traditions. These studies found that Chinese (Fang \& Wark, 1998), black people (Awosan, Sandberg, \& Hall, 2011) and Latino (Bermúdez, Kirkpatrick, Hecker, \& Torres-Robles, 2010) individuals generally seek help within their family and the community, and consider family therapy to be a last resort. However, studies did not specify which kind of help they received from their family, for example, if it were advices, mediation or other practices. One study reported that adolescents with prior contact with mental health services tend to be referred to family therapy rather than other treatments (Oliver et al., 1988), which reinforces the idea that family therapy is considered a last-resort treatment.

Gender. Seven studies, most of them quantitative in its nature, addressed the impact of gender differences in the search for couple therapy. These studies suggested that women were more likely than men to take the initiative in seeking psychotherapeutic help. Although this was mostly reported with regard to couple therapy, one article indicated that this pattern is also observed in the search for family therapy (O’Brien, 1988).

According to research, women play a more active role from the moment a problem is identified to the time when professional help is sought (Doss et al., 2003). Women also tend to have more favorable attitudes toward therapy (Bringle \& Byers, 1997). Furthermore, women tend to identify more relationship problems (Boisvert et al., 2011) and more reasons to seek therapy (Doss et al., 2004) than men. However, when sexual problems were present, men were more likely to play an active role in the search for therapy (Doss et al., 2003; Ficher, Zuckerman, \& Steinberg, 1988).

Some researchers suggested that these differences are associated with traditional male and female roles and are explained by sociocultural influences on men's and women's behavior. According to this hypothesis, men may be less likely to seek psychological help since recognizing and naming emotional problems, admitting 
to needing help and asking others for assistance are not congruent with traditional male role expectations (Englar-Carlson \& Shepard, 2005; O’Brien, 1988).

However, in spite of these sociocultural differences and of the fact that therapy-seekers are mostly female, studies suggest that men also play an important role in the psychotherapeutic process. For instance, Doss et al. (2004) found that men and women in general bring similar issues to therapy, and that there are no typically feminine or masculine problems. However, according to the authors, an analysis of the difficulties manifested by each couple suggests that each partner may be seeking therapy for a slightly different reason. These data suggest that the fact that women generally take more initiative in seeking help does not necessarily imply that men are unaware of relationship problems. As highlighted by Bringle and Byers (1997), even though they may not initiate the search for therapy, men may not object to the idea of psychotherapy, and may simply be more hesitant in seeking this type of help.

Relationship factor. The Relationship factor includes all features of the relationship itself, which may have an impact on the decision to seek professional help to resolve interpersonal conflicts. This theme was only found in studies of the search for couple therapy. All of these researches were empirical and had quantitative designs. The articles in which relationship factors were discussed found that men and women who reported lower marital satisfaction were more likely to seek marital therapy (Doss et al., 2003, Doss et al., 2009), and to name more reasons for help-seeking (Doss et al., 2004). Also, couples who made greater use of negative communication strategies were more likely to seek marital therapy (Doss et al., 2009), as were men who were unsatisfied with the affective communication in their relationships (Doss et al., 2003). Men who reported dissatisfaction with their current sexual life were more likely to participate in the help-seeking process, and, in the case of mutual aggression between partners, the wife tended to be more active in seeking therapy (Doss et. al., 2003).

In situations in which the wife was thought to have problems with alcohol use, couple therapy was often sought as a way for women to obtain greater support from their partners or to address specific relationship concerns during treatment (McCrady, Epstein, Cook, Jensen, \& Ladd., 2011). Another study found that individuals who sought marital therapy tended to have a lower acceptability of affectionate and intimate partner behaviors, as well as lower tolerance for partner violation behavior and partner demands (Doss \& Christensen, 2006). 


\section{DISCUSSION}

Most studies of the help-seeking process associated with couple and family therapy were recently published, with most researches on the topic being performed within the last ten years. Slightly over half the articles reviewed did not have the help-seeking process as a major focus, and addressed the topic as part of a larger research. These data support the idea that the help-seeking process for family and couple therapy is still a poorly investigated area.

Most of the studies identified were empirical researches with quantitative designs, and discussed couple rather than family therapy. The most widely researched influence on the help-seeking process of couples and families was the types of conflict reported by individuals. However, it was found that the reasons given for help-seeking do not always correspond to the dimension of the underlying problems. Such results corroborate literature, once that the reasons reported for seeking therapy are usually a part of an underlying conflict, and serve as a means of accessing more complex and systemic issues (Ríos González, 1998). Therefore, both in family and couple therapy, an effective treatment must begin by identifying the actual therapeutic demands underlying the problems reported at the beginning of treatment (Celano, Smith, \& Kaslow, 2010; Machado, Féres-Carneiro, \& Magalhães, 2011).

Studies of the way in which conflicts were handled prior to therapy suggested that both families and couples appear to use escalating strategies for conflict resolution. The first strategies used are commonly more general in their nature, and include searching for help from family and friends. The use of specific resources such as family or couple therapy appears to be a last-resort, and is usually only sought when none of the remaining strategies have proved successful. According to a systemic perspective, couples and families with a long history of conflict tend to employ problem-solving strategies which result in a momentary decrease in tension, but generally do not have any long-term effects on interpersonal functioning, since the system cannot survive without the symptom (Andolfi, Angelo, Menghi, \& Nicolo-Corigliano, 1984). This raises questions about the family factors and life circumstances which suddenly make couple or family therapy necessary. It is supposed that the exhaustion of emotional resources and the intensity of the symptoms may be associated with the decision to seek professional help; however this hypothesis has not yet been confirmed by the literature.

Studies regarding gender differences in the help-seeking process have found that women tend to play a far more prominent role in the search for couple and family therapy. In this condition, it is important to consider that the nature of the decision to seek help may have a decisive influence on the therapeutic bond 
and on the treatment process itself, since both couple and family therapy require the active involvement of all parties in a family or couple, as well as an impartial therapeutic stance (Friedlander, Kivlighan, \& Shaffer, 2012).

Studies of relational factors revealed that couples' assessments of their relationship are closely related to the decision to seek therapy. More specifically, help-seeking has been associated with low marital satisfaction, as well as dissatisfaction with partner communication and current sex life. However, few studies have evaluated the direct relationship between these relational dynamics and the decision to seek professional help. Therefore, the profiles or features of couples who do versus do not seek therapy have not yet been accurately clear. Our clinical experience suggests that the search for family or couple therapy requires positive relationship expectations. If individuals do not believe that their family or married life can improve, and that they can access the necessary resources to achieve such an outcome, they may not feel the need for outside help. Therefore, health promotion campaigns may play an important role in raising awareness about the possibility of having a better life, and of the potential contributions of couple or family therapy to this process.

In summary, the current review showed that the search for family and couple therapy is still a recent area of study, and has several gaps which require further research. However, the current literature allows for the following conclusions: a) the help-seeking process can be triggered by several different types of conflict, b) the manifest reasons for seeking professional help do not always reflect the underlying demands of couples and families, c) the frequency with which problems are mentioned may not correspond to the intensity with which they are felt by couples, d) families and couples tend to resort to informal sources of help before seeking therapy, which may delay the beginning of the therapeutic process; e) women tend to take the initiative in seeking professional help, and f) specific couple characteristics may also have an influence on the decision to seek professional assistance.

The following gaps in the literature were also identified: a) it has not been determined whether most couples and families attend therapy spontaneously or by referrals from other health professionals, b) the literature is not sufficiently clear about the features which may distinguish therapy-seeking from non-therapy-seeking couples and families, and c) the family characteristics or life situations which may trigger help-seeking have not been identified. The current literature has been unable to address these problems in their complexity, and further studies are required to elucidate the process involved in seeking family or couple therapy.

The current results must be interpreted in light of some limitations. Only 23 articles met inclusion criteria for the review, and the variability in the topics discussed by these studies limited the formation of conclusions regarding the help-seeking process. Furthermore, the current review focused only on articles 
retrieved by systematic database searches. Some authors have suggested that articles identified by non-systematic searches may also be included in literature reviews (Moher, Liberati, Tetzlaff, \& Altman 2009). The use of such techniques could have allowed for the identification and inclusion of a greater number of articles in the current study.

In spite of these limitations, the current results have important implications for clinical practice. Couple and family therapies are generally brief, and follow specific treatment plans. Therefore, the early identification of the circumstances implied in the treatment-seeking may be extremely helpful in establishing treatment plans and prognosis. For example, if the gender issues associated with the decision to seek professional help and the intensity of the problems reported by the couples or families are thoroughly investigated from the first therapy session, the actual treatment demands may be more easily identified, increasing client involvement in the therapeutic process.

Additionally, a more comprehensive understanding of the help-seeking process may help to promote autonomy among couples or families in conflict. The identification of family and couple characteristics associated with treatment-seeking and non-treatment-seeking, for instance, may contribute to the effectiveness of awareness campaigns and public policies designed to provide information to the public regarding the potential benefits of these types of therapy. Similarly, knowledge regarding the help-seeking process experienced by families and couples may contribute to the training of health care professionals and allow them to assess the need for couple and family therapy in different cases. This may streamline the help-seeking process for both families and couples and help direct clients to the appropriate treatment, facilitating their autonomy in the search for professional help, increasing treatment adherence, and reducing treatment waiting times.

\section{REFERENCES}

Adams, R. D., Aducci, C. J., Anderson, J. R., Johnson, M. D., Zheng, F., \& Liu, W. (2013). Marital therapy help-seeking attitudes of young adults in Mainland China. The American Journal of Family Therapy, 41, 63-71. doi:10.1080/01926187.2011.638573

Andolfi, M., Angelo, C., Menghi, P., \& Nicolo-Corigliano, A. M. (1984). Por trás da máscara familiar: Um novo enfoque em terapia de família. Porto Alegre: Artes Médicas.

Atkins, D. C., Marín, R. A, Lo, T. T., Klann, N., \& Hahlweg, K. (2010). Outcomes of couples with infidelity in a community-based sample of couple therapy. Journal of Family Psychology, 24, 212-216. doi:10.1037/a0018789 
Awosan, C. I., Sandberg, J. G., \& Hall, C. A. (2011). Understanding the experience of black clients in marriage and family therapy. Journal of Marital and Family Therapy, 37, 153-168. doi:10.1111/ j.1752-0606.2009.00166.x

Bardin, L. (2011). Análise de Conteúdo. São Paulo: Edições 70.

Bermúdez, M. J., Kirkpatrick, D. R., Hecker, L., \& Torres-Robles, C. (2010). Describing Latinos families and their help-seeking attitudes: Challenging the family therapy literature. Contemporary Family Therapy, 32, 155-172. doi:10.1007/s10591-009-9110-x

Boisvert, M.-M., Wright, J., Tremblay, N., \& McDuff, P. (2011). Couples' reports of relationship problems in a naturalistic therapy setting. The Family Journal, 19(4), 362-368. doi:10.1177/1066480711420044

Bringle, R. G., \& Byers, D. (1997). Intentions to seek marriage counseling. Family Relations, 46, 299$-304$.

Brown, J. (2008). We don't need your help, but will you please fix our children. Australian New Zealand Journal of Family Therapy, 29(2), 61-69.

Burgess, P. M., Pirkis, J. E., Slade, T. N., Johnston, A. K., Meadows, G. N., \& Gunn, J. M. (2009). Service use for mental health problems: Findings from the 2007 National Survey of Mental Health and Wellbeing. The Australian and New Zealand Journal of Psychiatry, 43, 615-23. doi:10.1080/00048670902970858

Celano, M. P., Smith, C. O., \& Kaslow, N. J. (2010). A competency-based approach to couple and family therapy supervision. Psychotherapy, Theory, Research, Practice, Training, 47(1), 35-44. doi: $10.1037 / \mathrm{a} 0018845$

Dennis, C.-L., \& Chung-Lee, L. (2006). Postpartum depression help-seeking barriers and maternal treatment preferences: A qualitative systematic review. Birth (Berkeley, California), 33, 323-331. doi:10.1111/j.1523-536X.2006.00130.x

Doss, B. D., Atkins, D. C., \& Christensen, A. (2003). Who's dragging their feet? Husbands and wives seeking marital therapy. Journal of Marital and Family Therapy, 29, 165-177.

Doss, B. D., \& Christensen, A. (2006). Acceptance in romantic relationships: The frequency and acceptability of partner behavior inventory. Psychological Assessment, 18, 289-302. doi:10.1037/1040-3590.18.3.289

Doss, B. D., Rhoades, G. K., Stanley, S. M., \& Markman, H. J. (2009). Marital therapy, retreats, and books: The who, what, when and why of relationship help-seeking. Journal of Marital and Family Therapy, 35, 18-29.

Doss, B. D., Simpson, L. E., \& Christensen, A. (2004). Why do couples seek marital therapy? Professional Psychology: Research and Practice, 35, 608-614. doi:10.1037/0735-7028.35.6.608

Ehrensaft, M. K., \& Vivian, D. (1996). Spouses' reasons for not reporting existing marital aggression as a marital problem. Journal of Family Psychology, 10, 443-453.

Englar-Carlson, M., \& Shepard, D. S. (2005). Engaging men in couples counseling: Strategies for overcoming ambivalence and inexpressiveness. The Family Journal, 13, 383-391. doi:10.1177/1066480705278467

Fang, S.-R. S., \& Wark, L. (1998). Developing cross-cultural competence with traditional Chinese Americans in family therapy: Background information and the initial therapeutic contact. Contemporary Family Therapy, 20, 59-77.

Féres-Carneiro, T. (1998). Clínica da família e do casal: Tendências da demanda contemporânea. Interações, 3(6), 23-32.

Féres-Carneiro, T., \& Magalhães, A. S. (2008). Novas configurações familiares e as repercussões em psicoterapia de família. Revista Brasileira de Psicoterapia, 10(2), 7-16. 
Ficher, I. V, Zuckerman, M., \& Steinberg, M. (1988). Sensation-seeking congruence in couples as a determinant of marital adjustment: A partial replication and extension. Journal of Clinical Psychology, 44, 803-809.

Friedlander, M. L., Kivlighan, D. M., \& Shaffer, K. S. (2012). Exploring actor-partner interdependence in family therapy: Whose view (parent or adolescent) best predicts treatment progress? Journal of Counseling Psychology, 59(1), 168-175. doi: 10.1037/a0024199

Gomes, I. C., \& Levy, L. (2010). Indicações para uma terapia de casal. Vínculo: Revista do NESME, $1(7), 13-21$.

Gulliver, A., Griffiths, K. M., \& Christensen, H. (2012). Barriers and facilitators to mental health help-seeking for young elite athletes: A qualitative study. BMC Psychiatry, 12(157). doi:10.1186/1471$-244 \mathrm{X}-12-157$

Kaltman, S., Mendoza, A. H. De, Gonzales, F. A., \& Serrano, A. (2014). Preferences for trauma-related mental health services among Latina immigrants from Central America, South America, and Mexico. Psychological Trauma: Theory, Research, Practice and Policy, 6(1), 83-91. doi:10.1037/ a0031539

Machado, R. N., Féres-Carneiro, T., \& Magalhães, A. S. (2011). Entrevistas preliminares em psicoterapia de família: Construção da demanda compartilhada. Revista Mal-Estar e Subjetividade, 11(2), 669-699.

McCrady, B. S., Epstein, E. E., Cook, S., Jensen, N. K., \& Ladd, B. O. (2011). What do women want? Alcohol treatment choices, treatment entry and retention. Psychology of Addictive Behaviors, 25, 521-529. doi:10.1037/a0024037

McManus S., Meltzer H., Brugha T., Bebbington P., Jenkins R. (Eds.). (2007). Adult psychiatric morbidity in England, 2007: Results of a household survey. (UK Report Data Archive Study Number 6379). London. Consultado em http://www.esds.ac.uk/doc/6379/mrdoc/pdf/6379research_report.pdf

Merikangas, K. R., He, J.-P., Brody, D., Fisher, P. W., Bourdon, K., \& Koretz, D. S. (2010). Prevalence and treatment of mental disorders among US children in the 2001-2004 NHANES. Pediatrics, 125, 75-81. doi:10.1542/peds.2008-2598

Moher, D., Liberati, A., Tetzlaff, J., Altman, D. G. (2009). Preferred reporting items for systematic reviews and meta-analyses: The PRISMA statement. PLOS Medicine, 6. doi:10.1371/journal. pmed 1000097

Nam, S. K., Choi, S. I., Lee, J. H., Lee, M. K., Kim, A. R., \& Lee, S. M. (2013). Psychological factors in college students' attitudes toward seeking professional psychological help: A meta-analysis. Professional Psychology: Research and Practice, 44, 37-45. doi:10.1037/a0029562

Neumann, A. P., \& Wagner, A. (in press). Caracterização da clientela atendida em terapia de família em uma clínica-escola. Psicologia Clínica 27(2), 63-81. Consultado em http://pepsic.bvsalud. org/scielo.php?pid=S0103-56652015000200004\&script=sci_arttext

O'Brien, M. (1988). Men and fathers in therapy. Journal of Family Therapy, 10, 109-123.

Ogden, T., \& Hagen, K. A. (2009). What works for whom? Gender differences in intake characteristics and treatment outcomes following multisystemic therapy. Journal of Adolescence, 32, 1425-1435. doi:10.1016/j.adolescence.2009.06.006

Olabuénaga, J. I. R. (2003). Metodología de la investigación cualitativa. Bilbao, España: Universidad de Deusto.

Oliver, J. M., Searight, H. R., \& Lightfoot, S. (1988). Client characteristics as determinants of intervention modality and therapy progress. American Journal of Orthopsychiatry, 58, 543-551.

Pieters, H. C., \& Heilemann, M. V. (2010). "I can't do it on my own": Motivation to enter therapy for depression among low income, second generation, Latinas. Issues in Mental Health Nursing, 31, 279-287. doi:10.3109/01612840903308549 
Reyes-Rodríguez, M. L., Ramírez, J., Davis, K., Patrice, K., \& Bulik, C. M. (2013). Exploring barriers and facilitators in eating disorders treatment among Latinas in the United States. Journal of Latina/o Psychology, 1, 112-131. doi:10.1037/a0032318

Ríos González, J. A. (1998). La familia hoy: Desconciertos y esperanzas. In J. A. Ríos González (Coord.), El malestar en la familia. (pp. 177-191). Madrid: Centro de Estudios Ramón Areces, S.A.

Sayer, N. A., Friedemann-Sanchez, G., Spoont, M., Murdoch, M., Parker, L. E., Chiros, C., \& Rosenheck, R. (2009). A qualitative study of determinants of PTSD treatment initiation in veterans. Psychiatry, 72, 238-255. doi:10.1521/psyc.2009.72.3.238

Smock, S. A., McWey, L. M., \& Ward, D. B. (2006). Rural versus urban clinical needs: Are there differences? Journal of Family Psychoterapy, 17, 37-49. doi:10.1300/J085v17n02

Teixeira, M. A., Lassance, M. C., Silva, B. M., \& Bardagi, M. P. (2007). Produção científica em orientação profissional: Uma análise da Revista Brasileira de Orientação Profissional. Revista Brasileira de Orientação Profissional, 8(2), 25-40.

Vogel, D. L., Wade, N. G., \& Haake, S. (2006). Measuring the self-stigma associated with seeking psychological help. Journal of Counseling Psychology, 53, 325-337. doi:10.1037/0022-0167.53.3.325

Wright, R. W., Brand, R. A., Dunn, W., \& Spindler, K. P. (2007). How to write a systematic review. Clinical Orthopaedics and Related Research, 455, 23-29.

Zartaloudi, A., \& Madianos, M. G. (2010). Mental health treatment fearfulness and help-seeking. Issues in Mental Health Nursing, 31, 662-669. doi:10 